\title{
Market Analysis of Agricultural Production Mode Selection*
}

\author{
Rong Qiu \\ Guizhou University of Finance and Economics \\ Guiyang, China
}

\author{
Yini Liu \\ Guizhou University of Finance and Economics \\ Guiyang, China
}

\begin{abstract}
Theoretical research as well as the real practice on whether the current agricultural production mode should engage a larger scale is not quite clear. Combining with the relevant theories of economics, this paper argues that the selection on taking dispersed mode of agricultural production or large-scale production should be based on the capital labor ratio of factor market and commercialization rate of product market. Agricultural production elements configuration and product market commercialization rate in China currently is also analyzed in this paper. The findings suggest moderate scale mode should be adopted in China agricultural production.
\end{abstract}

Keywords - agricultural production mode; capital labor ratio; commercialization rate of product market

\section{PRODUCT MARKET, FACTOR MARKET AND PRODUCTION MODE SELECTION}

Mode of production refers to the measurements of getting materials for human survival and development under certain level of productivity and production relation framework. Productivity is human's ability to transform and utilize nature with no social attributes. The three determinants of productivity include laborer, labor tool and object of labor. Laborer is the most active factor. Labors with higher education can provide conditions for the promotion and usage of advanced technology. Technical innovation belongs to the category of productivity. Higher productivity can be generated by laborer with higher education degree and advanced labor tool used by the object of labor, in order to obtain labor products with larger quantity and better quality. According to the interpretation of the western economics, it is the allocation of labor, technology, capital and land. Production relations refer to the social relations between people established in the process of production, exchange, distribution, and consumption. It is also formed in the process of resource allocation. Institutional change is the adjustment of the production relations with transactions of property right relations. Property right relations include ownership, right to use and assignment right, among which, the most important one is ownership, especially the ownership of production materials. The reform is to accelerate the development of productivity by adjusts the factor market and product market rules on the basis of the

*This paper is one of the research results of the "Research on the Development of Agricultural Informatization and the Development of Agricultural Modernization in Guizhou" by the Department of Education of Guizhou Province in 2014. Item Number: JD2014112. existing public ownership and follow the rules of productivity development, as well as adjust production relations by adjusting the system. Deepening the reform of agriculture is similar. In agricultural production, public ownership of production material and land is the unshakable fundamental basis of the socialist system. In Marx's works, mode of production includes three meanings, referring as the mediation of productivity and production relations, productive relations and means of labor. Mode of production here only means mode of labor, which can be separated in centralized and decentralized ways.

In the period of low level productivity, capital and technology are less important than labor in the factors allocation. Labor factor need to find autonomy and actively cooperate with capital and technological factors. Such situation determines the dispersed mode of agricultural production. The improvement of agricultural production technology progress and labor tools and the improvement of quality of labors, otherwise, will change the factor allocation. More capital and technological factors will be involved. The profit-driven characteristic of capital leads to a pursuit of economies of scale, which pushes agricultural production from decentralized to centralized way. At the same time, commercialization of agricultural products can expand trading range, increase trade volume and decrease transaction cost, which will promote scale production in turn. A higher commercialization rate of agricultural products can also lead to a faster payback on production materials, which makes material owners to become more sensitive to the market situation. Product market and factor allocation form a tight circle, which is driven by repeating transactions. With the improvement of production technology, more surplus products and higher degree of commercialization rate can be achieved. In which case, producers can get more incentives from the market, thus, they have more motivations to improve techniques and input capital, as shown in the left side of "Fig. 1". And once the proportion of capital increased to a certain level in the factor allocation, the nature of capital will force the production mode to transfer from decentralized production to scale production, as shown in the right side of "Fig. 1". 


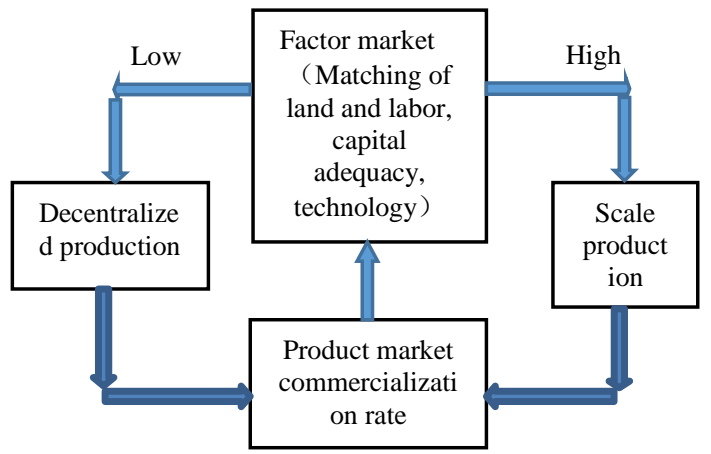

Fig. 1. Product market, factor market and production methods.

Scale production requires relatively abundant capital in the factor market, with corresponding agricultural production techniques and tools. Labors which have the ability to use such techniques and tools, land, as well as relatively high commercializing rate are also necessary. If the conditions discussed above cannot be satisfied, decentralized production mode will be more suitable.

\section{Current Agricultural Production Mode CHOICE: MODERATE SCALE}

Since late 1990s, in order to ensure strategic grain reserves and promote agricultural development, China had canceled agricultural tax, reduced the burden on farmers and implemented grain subsidies, which further stimulated the farmers' production enthusiasm. Strict division of urban and rural dual economy is broken. The transfer of rural surplus labor reduces the number of labor available in agricultural demand. At the same time, the farmers become more and more dependent on pesticide and chemical fertilizer usage to improve output in the process of production. In areas with sufficient land resource, the reduction of agricultural labor motivates producers to use machine instead of labor which also will increase production scale. All of the factors above has on one side, increased the capital-labor ratio in agricultural production. On the other side, transactions on agriculture production factors have been increased, as well as the transaction cost. In agricultural postpartum sales process, increase in the number of agricultural production and commercialization rate will increase the selling cost of single farmer. Capital labor ratio's increase in agricultural production and higher level of agricultural commercialization rate will push the transition of agricultural production mode from decentralized production to scale production.

\section{CURRENT SituAtion OF AgricUltural PRODUCTION FACTOR MARKET IN CHINA}

\section{A. The Elements of Labor}

With the reform of market, the fence between rural and city had been tear down and laborers can transfer disengaged. Returning farmland to forest, agricultural mechanization promotion makes the number of rural surplus labor force to further increased, many rural in Midwest appear "shell" phenomenon, which is commonly known as the "993861 forces", elders, children and women were the vast majority of the elderly in rural areas, and young men were left. Macro statistics also show that agriculture, forestry, animal husbandry and fishery labor is decreasing, except for very few years, such as 1999. Because of the Asian financial crisis, urban laborers reduction, rural surplus labor force to return home and looking for jobs, in other year agricultural laborers decreased year by year. Compared with 1992, the absolute number decreased by 70.5 million in 2012. With the development of urbanization, agricultural labor force will continue to flow from rural to urban areas. At the same time, the quantity of agricultural labor force is decreasing due to the implementation of compulsory education lead the quality of agricultural labor force has improved, which provides the conditions for scale production.

\section{B. The Land Element}

China's arable land area of 95 million 672 thousand hectares in 1990, in 2008 was 121 million 716 thousand hectares. The change of cultivated land area is divided into two obvious periods: from 1990 to 1995 , the total cultivated land was maintained at about 95,000 thousand hectares. Since 1996, the number of cultivated land has increased to 1 , 30039 thousand hectares due to reclamation land. Later, due to the management of soil erosion and returning farmland to forest and urbanization of agricultural land into a construction land, the total area of cultivated land decreased slightly year by year as shown in "Fig. 2", but always above the red line of 18 million mus.

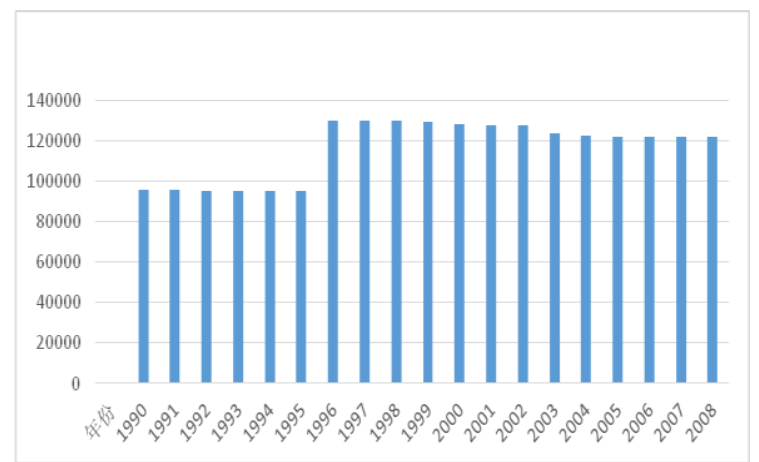

Fig. 2. Changes of cultivated land area from 1990 to 2008. Unit: thousand hectares

\section{Capital Investment}

In 12 years From 2003 to 2014, the total investment in fixed assets increased from RMB 165.5 billion to RMB 1,6573 billion in agriculture, forestry, animal husbandry and fishery, an increase of nearly 10 times, but its share of total investment in fixed assets stabilized at around $0.30 \%$ as shown in "Table I". The added value of the primary industry increased from RMB169.7 billion in 2003 to RMB5, 534.3 billion in 2014, more than three times as much as the proportion of its gross domestic product (GDP) decreased from $12.34 \%$ in 2003 to $9.05 \%$ in 2014 . There is Data shows that $0.3 \%$ of fixed assets investment in agriculture, forestry, animal husbandry and fishery create $9 \%-12 \%$ of GDP output, investment is efficient, but the proportion of 
investment is stable at $0.30 \%$. The reason may be related to the high risk of agricultural production. Agricultural production risk not only from the market factors, but also by the geographical, weather, natural disasters, pests and diseases and so on, and cannot be used to defuse the risk of insurance. It can be said that lagging agricultural production insurance is one of the main reasons for the long-term investment in fixed assets always in a low level in agriculture.

TABLE I. THE RATIO OF INVESTMENT IN FIXED ASSETS FROM AGRICULTURE, FORESTRY, ANIMAL HUSBANDRY AND FISHERY AND TOTAL INVESTMENT IN FIXED ASSETS IN 2003 TO 2014

\begin{tabular}{|l|l|l|l|}
\hline Time & $\begin{array}{c}\text { Capital } \\
\text { investment (\%) }\end{array}$ & Time & $\begin{array}{c}\text { Capital } \\
\text { investment (\%) }\end{array}$ \\
\hline $\mathbf{2 0 0 3}$ & 0.29 & $\mathbf{2 0 0 9}$ & 0.30 \\
\hline $\mathbf{2 0 0 4}$ & 0.26 & $\mathbf{2 0 1 0}$ & 0.31 \\
\hline $\mathbf{2 0 0 5}$ & 0.26 & $\mathbf{2 0 1 1}$ & 0.28 \\
\hline $\mathbf{2 0 0 6}$ & 0.24 & $\mathbf{2 0 1 2}$ & 0.29 \\
\hline $\mathbf{2 0 0 7}$ & 0.24 & $\mathbf{2 0 1 3}$ & 0.30 \\
\hline $\mathbf{2 0 0 8}$ & 0.29 & $\mathbf{2 0 1 4}$ & 0.32 \\
\hline \multicolumn{3}{|c|}{ a. Source: According to the International Bureau of Statistics website } \\
\hline
\end{tabular}

\section{Technical Element}

This paper uses the number of small agricultural tractors to reflect the changes in agricultural technology elements. As a result of the substantial increase in the area of cultivated land in 1996, the number of small-sized tractors used in a thousand hectares decreased and the number of small-sized agricultural tractors per 1000 hectares increased year by year after returning to 1995 levels in 1999. Although the number of cultivated land in recent years has not been obtained, but because the state requires the relevant departments to strictly adhere to 18 million mu of arable land which is called "red line" , so even if there have some changes, it must only be a slight fluctuation. It can be calculated that the number of thousands of hectares of small tractors is 150 or so at the end of 2014.

\section{CURRENT STATUS OF CHINA'S AgRICULTURAL PRODUCTS MARKET}

China's agricultural products market is characterized by the imbalance between supply and demand structure, that is, for the provision is not needed, the need is not available. With the improvement of consumption level, the quality of demand for agricultural products has also improved, but there are many things that make consumers worry about the quality of domestic agricultural products, reducing consumer confidence, such as excessive use of pesticides and fertilizers that make the quality of the soil has change, The heavy metal content of agricultural products exceeded the standard, what's more, the poisonous rice event. On the one hand, the market showed that the domestic production of agricultural products oversupply, sales difficulties, on the other hand consumers have a high demand aspirations of foreign agricultural products. The food market is more representative. China's grain production has been to a new high, to achieve continuous 12-year growth in 2015. At the same time, there is a phenomenon which is food production, stocks and imports are growing at the same time. Xiwen Chen, director of the office , CPPCC National Committee member, deputy director of the central rural work leading group, think that the structural asymmetry of production and consumption, that is, the structural contradiction of supply and demand of agricultural products, is an important factor in the growth of the above three variables. However, the reduction of agricultural population, the increase in agricultural production, the commercialization rate of agricultural products is bound to rise.

\section{The Choice of Agricultural Production Mode IN CHINA}

From the allocation of elements, the agricultural production in our country has many characteristics: the arable land can maintain the level of 18 million, agricultural production of fixed asset investment accounted for roughly basically stable at $0.30 \%$, agriculture, forestry, animal husbandry and fishermen employees decreased year by year, the educational level of laborers are increasing, the degree of agricultural mechanization is advancing steadily, the technology of agricultural production is continuously improving. On this basis, we can make a conclusion: the ratio of capital and labor force has a rising trend. At the same time, the commercialization rate of agricultural products market gradually increased. Therefore, the agricultural production mode should choose the scale of production, and it's a trend all over the world. In plain areas where the land is flat, the scale can be produced through land transfer and mechanized farming. In the rural areas of mountainous areas, there are few flat landslides, poor land flatness, and the substitution of agricultural machinery is quite low for labor factors. Factor acquisition and product sales can achieve large-scale, but decentralized production is the best way to minimize production supervision costs in production process. Combined with China's agricultural production conditions and agricultural policy practice, promoting the scale of production in all regions is clearly unreasonable. Therefore, at present, China's agricultural production should be moderate scale production.

\section{CONCLUSIONS AND IMPLICATIONS}

The choice of decentralized production or scale production depends on these three following production conditions: the natural conditions of land, the ratio of capital and labor factors, and the commercialization rate of agricultural products. That is, if a region has a good land flatness, high rate of capital labor factors, high commercialization of agricultural products in the region, that can implement the scale of production; and if a region has a bad land flatness, low rate of capital labor factors, low commercialization of agricultural products in the region, the factor acquisition and product sales can achieve large-scale, but decentralized production. While in the low rate of capital labor factor, the low rate of commercialization of agricultural products, we should choose the decentralized production.

Measures to promote the scale: firstly, to improve the capital labor ratio. It can be realized by promoting the social security of rural residents and peeling off the security function of the land to squeeze out the surplus labor force in 
the countryside. At the same time, further implement and extend compulsory education are required to improve the quality of agricultural workers. Meanwhile, to increase investment in agricultural production, speed up agricultural infrastructure construction, promote agricultural mechanization, accelerate agricultural production insurance, and attract private investment in agriculture. Secondly, rely on the important producing areas according to climate and land conditions. In these circumstances, we can implement the scribe area management; highlight the characteristics, to improve the commercialization rate of agricultural products.

\section{REFERENCES}

[1] Naiming Wang. China's agricultural production mode transformation process and its choice. Climbing, 2013/6.

[2] Ruyao Ying, Xuyuan Zheng. Resource endowment, factor substitution and transformation of agricultural production and operation mode: a case study of grain production in Jiangsu and Zhejiang provinces. Issues in Agricultural Economy, 2013/12.

[3] Wen Zhao, Jie Cheng. Agricultural production mode change and farmer economy incentive effect. Chinese Rural economy, 2014/2.

[4] Yinan Li, Hong Qiu. Research on the Transfer and Employment of Rural Surplus. Population Journal, 2014/6.

[5] Land and Resources Bulletin of 2015. Ministry of Land and Resources of 2016 in China.

[6] Nan Zhao, Tao Zhao. Study on the Regional Characteristics of China's Agricultural Surplus Labor Force. Journal of Yunnan Nationalities University, 2016/1.

[7] Yishu Wang. Marx's theory of agricultural production and its practical reflection (Volume I and II). Theoretical perspective, 2014/6. 